\title{
DEVELOPING A STRATEGY FOR THE PROTECTION OF TRADITIONAL AGRICULTURAL LANDSCAPES BASED ON A COMPLEX LANDSCAPE-ECOLOGICAL EVALUATION (THE CASE OF A MOUNTAIN LANDSCAPE IN SLOVAKIA)
}

\author{
Jana ŠPULEROVÁ, Marta DOBROVODSKÁ, Zita IZAKOVIČOVÁ, Pavol KENDERESSY, \\ František PETROVIČ, Dagmar ŠTEFUNKOVÁ
}

\begin{abstract}
Traditional agricultural landscapes (TALs) in Slovakia are mosaics of small-scale arable fields and permanent agricultural cultivations resulting from continuous succession over centuries. The objective in this paper is to develop a strategy for the protection and management of TAL in the Liptovská Teplička cadastral area, which has mountainous arable land and grassland TALs. Driving forces, threats and other trends related to these TALs were identified, based on the valuation of land-use changes, socioeconomic and demographic phenomena and on biodiversity and sociological research. The strategy was oriented towards optimal multi-functional utilization and management of the investigated landscapes.
\end{abstract}

\section{Shrnutí}

\section{Rozvoj strategie ochrany tradičních zemědělských krajin založené na komplexním krajinně-} ekologickém hodnocení (na příkladu horské krajiny na Slovensku)

Tradiční zemědělská krajina je tvořena mozaikovou strukturou extenzívně využívaných maloplošných prvků orné půdy a trvalých kultur, které se tu vytvořily plynulou sukcesí trvající několik století. Cílem studie bylo vypracovat strategii pro ochranu a management tradiční zemědělské kraji v katastrálním území Liptovské Tepličky, které představuje typ tradiční horské polně-luční zemědělské krajiny. Výzkum byl zaměřený na změny využíuání krajiny, hnací síly, ohrožení a trendy tradiční zemědělské krajiny. Návrh strategie je zaměření na optimální multifunkční využití a návrh managementu pro studované území.

Keywords: traditional agricultural landscape, management, measures, biodiversity, Slovakia

\section{Introduction}

Traditional agricultural landscapes (TALs) are described as landscapes where traditional sustainable agricultural practices are currently carried out and biological diversity is conserved (Harrop, 2007). TALs in Slovakia comprise a mosaic of small-scale arable fields and permanent agricultural cultivations, including grasslands, vineyards and high-trunk orchards originating from continuous succession over centuries (Štefunková, Dobrovodská, 1998). They are significant as unique islands of species-rich plant and animal communities. History has recorded many successive and even devastating landscape changes, which have barely left any TAL relics today (Benayas and Bullock, 2012; Marini et al., 2011). These changes are regarded as a menacing adverse development because they have engendered loss of diversity, coherence and identity characteristics of TALs, which are rapidly vanishing (Antrop, 2005a; Supuka, Stepankova, 2006). Traditional land-use systems in Europe have mainly persisted in upland and remote areas where physical constraints have prevented agricultural modernisation (Plieninger et al., 2006). The Slovak TAL inventory has determined the area of delimited TALs at 42,085 ha, and this comprises merely $0.9 \%$ of the entire territory of Slovakia (Špulerová et al., 2011). However, these areas are currently not subject to special protection and trends in declining management and abandonment are quite apparent.

On the other hand, these landscapes are significant not only from the biodiversity viewpoint, but they also have irreplaceable ecological, cultural and historical values, beneficial for society. For example, 
they play an important role in water retention and soil erosion control - both important with respect to climate change.

It is only in recent decades that the link between traditional European agricultural landscapes and biodiversity has been investigated and the importance of European agri-biodiversity recognized (Pedroli et al., 2007). Case studies involving multidisciplinary investigation of TALs, landscape history, forces driving the land-shaping system and land management methods have been analyzed, together with landscape preservation strategies. These are of great value from both nature and heritage conservation perspectives (Kizos et al., 2010; Petanidou et al., 2008; Cullotta and Barbera, 2011; Petit et al., 2012, and others). Interest in maintaining the integrity of traditional landscapes also emerged from the European Landscape Convention (ELC, 2000), following realistic threats of the loss of traditional landscapes.

The concept of High Nature Value (HNV) agricultural areas was developed within the Common Agricultural Policy (EU/1257/99). This ensued from a project for the European Environment Agency, focused on the identification of High Nature Value (HNV) farmland (Andersen et al., 2003; EEA/UNEP, 2004). The following three types of HNV farmland were defined (Paracchini et al., 2006):

1. (I) Farmland with a high proportion of semi-natural vegetation;

2. (II) Farmland with a mosaic of low intensity agriculture and natural and structural elements; and

3. (III) Farmland supporting rare species or a high proportion of European or World populations.

Although the HNV concept has not been effectively implemented in the current Slovak policy, national authorities have already created an expert platform to identify HNV indicators and the extent of HNV farmland (Plassmann, 2013).

The first attempt to identify HNV farmland in Slovakia was based on remote sensing data and information on species and habitat type distribution listed in the Annexes of the Habitat directive (Halada et al., 2011). In the Slovak Agricultural Agency spatial attention is currently concentrated only on type I species rich grassland. Extensively utilized mosaics of TALs together with structural elements such as Forms of Anthropogenic Relief (FAR) represented by stone walls, terraces and mounds, and natural elements including field margins, hedgerows, patches of woodland or scrub and small rivers, form the type II Farmland with a mosaic of low intensity agriculture. Type II allocation is based on indicators and results from the Slovak countryside TAL inventory of 2009-2011 (Špulerová et al., 2011). This utilized a combination of land cover and farming system approaches with research on biodiversity.

The main aim of the research reported here is to highlight the significance of TALs, their biodiversity and threats, and to propose the most suitable management plan through studying the Liptovská Teplička pilot area. This area was selected because it reflects actual land use and management approaches, natural, socio-economical conditions and TAL protection and management strategies. TALs in this Liptovská Teplička cadastral area consist of characteristic mosaics of small strip fields and balks in a preserved cultural-historical landscape.

\section{Materials and methods}

Research into a cultural landscape is based on holistic principles, which integrate scientific disciplines. The trans-disciplinary landscape concept is based on the following five landscape dimensions; spatial entity, mental entity, temporal dimension, the interrelationship of nature and culture, and systemic landscape properties (Tress and Tress, 2001). The landscape is studied as a hierarchical structure to reduce its extreme complexity to more comprehensive entities. The most important task in landscape studies is to define a scale indirectly derived from map surveys and resolution sampling (Antrop, 2005b). Intensive interaction between decision makers, researchers and landscape users is required in TAL studies. Scientific principles are utilized to understand the processes and spatial ecological structures and to restore, maintain and create traditional land use systems (Vos and Meeks, 1999). Developing instruments for practice and policy making such as scenario studies, monitoring systems and implementation of expert management systems, are highly recommended (WLO, 1998).

It is essential to understand the spatial and temporal intersection and interaction of landscape socioeconomic, abiotic and biotic systems, in order to determine the current trends and threats to agrarian landscape heritage preservation, and to define TAL scenarios and management strategies. Herein we present a methodological approach to develop a strategy for TAL protection based on a complex landscape ecological assessment (Tab. 1). We were inspired by LANDEP methodology (Ružicka and Miklos, 1990) and by other methods and case-studies based on multidisciplinary integration and multiscale approaches (Cullotta and Barbera, 2011; Ellis et. al., 2009; Van Eetvelde and Antrop, 2004). 


\begin{tabular}{|c|c|c|c|}
\hline \multirow{2}{*}{$\begin{array}{l}\text { Landscape scale/ } \\
\text { landscape system }\end{array}$} & \multicolumn{3}{|c|}{ Landscape - ecological analysis } \\
\hline & Abiotic conditions & Biotic conditions & Socio-economic and cultural conditions \\
\hline Cadastral area & $\begin{array}{l}\text { - Geology } \\
\text { - Soils } \\
\text { - Geomorphology } \\
\text {-Hydrology }\end{array}$ & $\begin{array}{l}\text { - Potential vegetation } \\
\text { - Natural - semi-natural biotopes }\end{array}$ & $\begin{array}{l}\text { - Past and present land cover/land-use } \\
\text { - Socio-economic negative and } \\
\text { positive impact } \\
\text { - Landscape heritage features } \\
\text { - Demographic structure } \\
\text { - Sociological research }\end{array}$ \\
\hline \multirow[t]{2}{*}{$\begin{array}{l}\text { Selected TAL } \\
\text { sites }\end{array}$} & $\begin{array}{l}\text { - Geological substrate } \\
\text { - Soils }\end{array}$ & $\begin{array}{l}\text { - Zoological inventory of selected } \\
\text { fauna groups } \\
\text { - Phyto-coenological inventory }\end{array}$ & $\begin{array}{l}\text { - Land cultivation } \\
\text { - Traditional techniques } \\
\text { - Forms of anthropogenic relief }\end{array}$ \\
\hline & \multicolumn{3}{|c|}{ Landscape - ecological synthesis and evaluation } \\
\hline $\begin{array}{l}\text { Selected TAL } \\
\text { sites }\end{array}$ & \multicolumn{3}{|c|}{$\begin{array}{l}\text { - Biodiversity and ecological value } \\
\text { - Cultural-historical value }\end{array}$} \\
\hline Cadastral area & \multicolumn{3}{|c|}{$\begin{array}{l}\text { - Land-use trends } \cdot \text { Cultural-historical value of TAL } \bullet \text { Ecological value of TAL } \\
\text { - Driving forces and threats to TAL } \\
\text { - Elaboration of } 3 \text { scenarios and consultation with stakeholders }\end{array}$} \\
\hline & \multicolumn{3}{|c|}{ Proposals } \\
\hline \multirow{2}{*}{ Cadastral area } & \multicolumn{3}{|c|}{ - Practical management measures of TAL } \\
\hline & \multicolumn{3}{|c|}{ - Strategy for sustainable utilization and protection of TAL } \\
\hline
\end{tabular}

Tab. 1: Methodology of complex landscape-ecological evaluation to develop a protection strategy for traditional agricultural landscapes

The complex landscape-ecological evaluation consisted of an analysis of landscape conditions at cadastral area level (landscape meso-scale) and selected TAL site levels (micro-scale). Landscape synthesis and assessment resulted in a strategy and practical measures for TAL management.

The landscape analysis at the cadastre level was focused not only on natural landscape components, land-cover/land-use and socio-economic conditions, but also included a TAL demographic and cultural heritage analysis and sociological research. The analysis of socio-economic conditions was based on the following:

1. Identification of human interaction with natural resources with positive impact (such as legislative measures for nature protection, protection of natural, cultural and historical resources, and also ecologically significant landscape elements currently lacking legislative protection); and

2. Those with negative impacts, thus posing threats to TALs and other natural resources

Demographic conditions were evaluated on the basis of population age structure, population movements, economic structure, employment and unemployment, and educational, ethnic and religious population structure. The sociological research on farmers and stakeholders perceptions of TALs was implemented by semi-structured interviews with five key stakeholders (mostly local farmers and decision makers) and from a questionnaire survey of local inhabitants, the latter involving $5 \%$ of permanent residents, with 230 respondents. The interviews were focused on the identification of underlying driving forces in landscape change, and agricultural policy effects on farmer's livelihoods and farm management. The questionnaire survey provided quantitative data on farmers and their farming practices. The total sample was divided into recent farmers in the 2000s, farmers from the 1970s, 1980s and 1990s, non-farmers, potential farmers from farming families, and other remaining respondents (Lieskovský et al., 2013).

Phyto-sociological sampling was performed on all non-forest habitats within the cadastre area, with a detailed fauna and flora inventory for selected TAL sites with different types of traditionally managed agricultural plots and FARs. The following fauna groups indicated habitat ecology; Mollusc (Molusca), Millipedes (Diplopoda), Beetles (Coleoptera), Birds 
(Aves), Grasshoppers (Orthoptera) and Butterflies (Lepidoptera). Soil analysis, FAR inventory, cultivation type and agricultural technique were analyzed for selected TAL sites.

Landscape-ecological synthesis and evaluation consisted of identifying TAL localities, and land use trends assessment at the cadastral level. TAL sites comprised areas with preserved continuity of agricultural use, and their distribution in the study areas was identified through a comparison of current and historical maps depicting the state of land use in three time horizons (Štefunková et. al., 2013).

Biodiversity and cultural-historical values were assessed in monitoring plots with different types of TAL structures. The biodiversity assessment centred on the evaluation of species abundance, habitat diversity and vulnerability of species, based on vegetation and zoological surveys and existing ecological conditions. The cultural and historical value was determined by using a range of preservation and traditional cultivation techniques and original land terracing with FARs.

The main driving forces and threats to TALs were identified from knowledge of abiotic, biotic and socioeconomic landscape conditions, from the results of the sociological research, and from past and current land use trends. Knowledge of biodiversity and cultural and historical value of the TAL sites was also included for this purpose.

Modelling scenarios: Three visual scenarios were derived from photomontages. These were based on the identified land-use changes, driving forces and TAL threats and trends, (software Adobe Photoshop 7.0). They depicted TAL disintegration trends, traditional TAL management maintenance and TAL abandonment. These scenarios were then discussed with local stakeholders.

The outcome provided a strategy for TAL protection and management consisting of practical management measures for different TAL types, and strategic development goals focused on key TAL objectives and based on sustainable development principles.

\section{Results}

\subsection{Complex landscape-ecological evaluation of the pilot area}

This research was performed in the Liptovská Teplička cadastre situated in a small basin surrounded by mostly steep $\left(12^{\circ}-17^{\circ}\right)$ or moderate slopes in the Low Tatra Mts. (Fig. 1) at altitude ranges from 846-1,429 m a.s.l. Natural conditions comprise a wide spectrum of geological bedrocks (predominantly limestone and dolomites), related soils, relief segmentation and varied micro-climatic conditions. Goral settlers colonized the village with preserved typical wooden architecture in the $17^{\text {th }}$ century. Specific FARs were created during the period of terrain modification for agricultural production. This landscape has a strip-like structure of small-scale plots, which create an attractive framework in the forested Low Tatra Mts. The area has sub-regions with a specific combination of natural and cultural diversity and high landscape visual quality.

The current dominant landscape structure encompasses grasslands differentiated by land use activity including intensively or extensively utilized meadows or pastures, some of which are tessellated or have lengthwise mounds. Extensively utilized meadows of grass-covered former arable fields cover the largest area of this grassland. The seminatural meadows comprise small remnants of former mountain hay meadows, which, together with haylofts, retain the typical mountain landscape features existing before collectivisation. The most important landscape interventions linked to the establishment of an agricultural committee and collectivization began in 1975. Meadows situated in remote areas from settlements were transformed into pastures. The depression of agriculture continued until 1991, when re-privatization of agricultural land was connected with extensive agricultural development and the commencement of organic farming. Currently, most agricultural land is cultivated by the Agricultural Cooperative of Liptovská Teplička, which has leased land from private owners, and adopted organic farming since 1996 on the entire agricultural land area. They currently cultivate approximately 1,275 ha of farmland, 60 ha of which is arable land; meadows and pastures represent the remainder.

Traces of preserved traditional agriculture remain in five different types of TAL mosaic under different management intensity and with the presence of various FARs (Fig. 1). The different FAR types such as balks, terraces and mounds result from improved topography-soil quality, and these are either further directly cultivated and improved by stone removal or remain uncultivated (Fig. 2). Depending on the proportion of the soil/stone content, the FARs are categorized in three groups: muddy, muddy-rocky and loamed-rocky (Fig. 3).

TALs often create specific living conditions for biota of high biodiversity and also support many rare and endangered species. The biodiversity assessment herein centred on species richness in natural and semi-natural habitats and on habitats conditioned by anthropogenic activities such as FARs. More than 200 plant species 


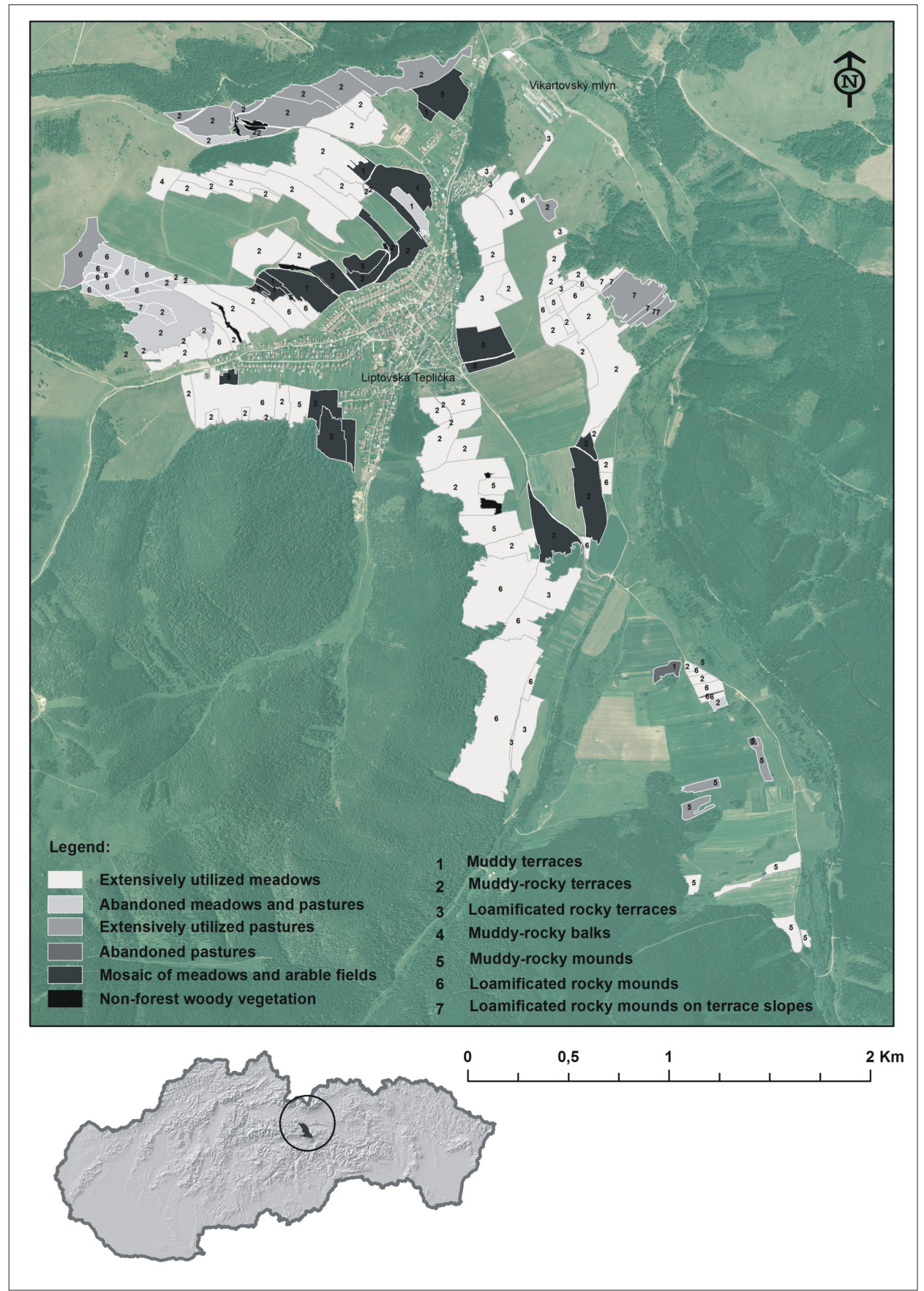

Fig. 1: Distribution of different types of traditional agricultural landscapes with the presence of Forms of Anthropogenic Relief in the Liptouska Teplička cadastral area

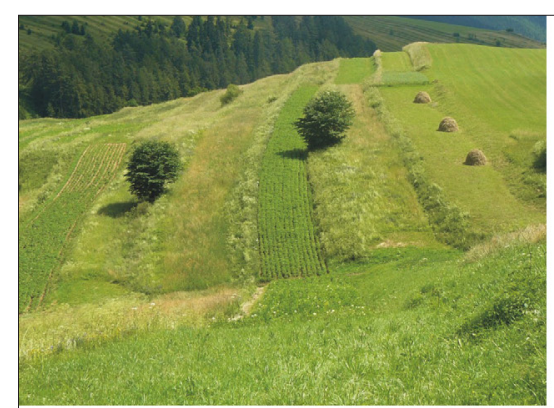

a)

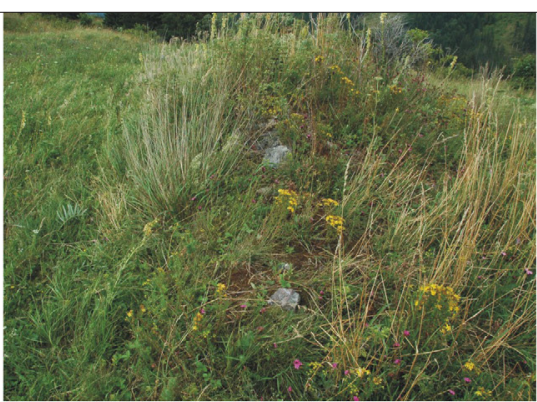

b)

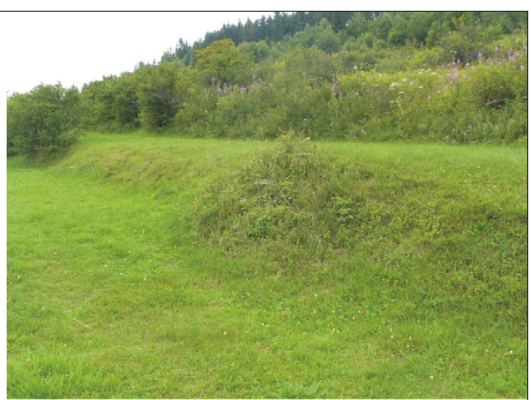

c)

Fig. 2: Forms of Anthropogenic Relief: a) Terraces, b) Mounds, c) Mounds on terrace slopes 


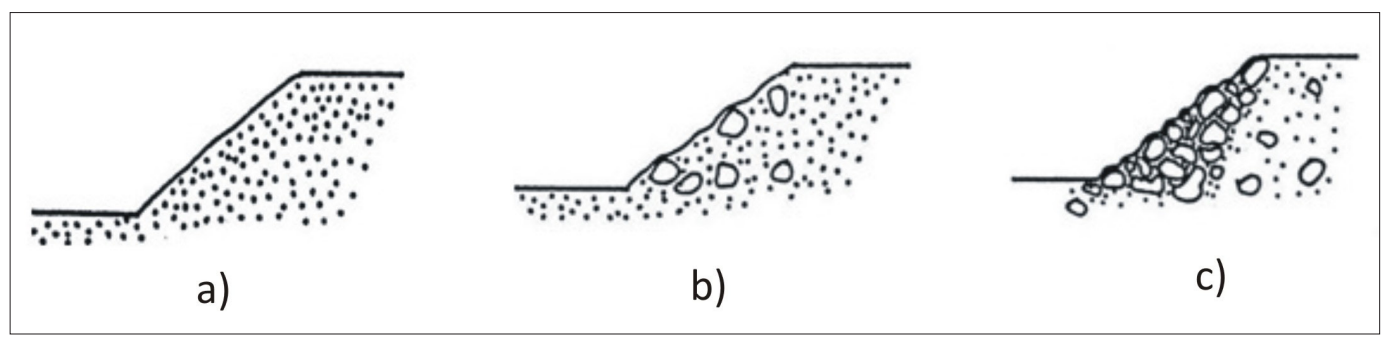

Fig. 3: The stone and soil content of the Form of Anthropogenic Relief: a) muddy, b) muddy-rocky, c) loamyrocky terraces

were recorded on grassland habitats, including several endangered and/or protected species (Ružičková, Dobrovodská, 2006).

The TAL dominant structure here is extensively used meadows with either muddy-rocky terraces or rocky mounds. The species composition is affected by environmental conditions and management intensity with the highest abundance recorded for semi-natural species, rich mesophilous meadows connected to humid mountain areas. However, pastures affected by collectivisation are characterized by low species abundance. Extensive agriculture and organic farming affected the extent of species richness of grasscovered former arable fields. Grass-covered terraces and mounds show high species richness increased by the occurrence of regionally rare species untypical of meadows and usually connected with rocky habitats. The research results for selected animal groups revealed their current status and favourable conditions for diversity (Dankaninová, Gajdoš, 2011).

The village of Liptovská Teplička had a population of 2,359 in 2009, and statistics show a positive trend in population increase in the large rural settlement area (http://portal.statistics.sk). In terms of age structure, $60 \%$ of the population is in the productive age group and $25 \%$ in pre-productive age, while only $15 \%$ is in the post-productive age group. A greater part of economically active residents work in manufacturing (195), forestry, logging and related services (185), and in agriculture and tourism (70). Although they work in nearby cities, such as Poprad in the High Tatra Mts., and often travel abroad for a better job, there is no direct evidence of labour migration (Moyzeová, 2012).

The assessment of positive and negative socioeconomic phenomena indicates very high environment quality in the study area, as this area is part of the Low Tatra National Park and Natura 2000 sites. Ecologically important landscape segments include wetlands, cultural-historical landscape features and historic urban structures, and the landscape is unaffected by significant negative socio-economic impacts (Moyzeová, 2012).

\subsection{Driving forces}

Landscapes are the result of many layers of past natural processes and human interventions (Brandt et al., 1999). Driving forces involved in TAL maintenance and other observed landscape changes are identified as follows:

- Natural conditions and geographic location for TAL existence: steep or moderate slopes and relatively high altitude (Fazekašová et al., 2013). Stony soils formed less favourable conditions for agriculture, leading to the creation of FAR. A broad spectrum of geological bedrocks from limestone to flysh sandstone influence high species richness and habitat diversity;

- Long tradition in extensive land management with traditional extensive agricultural technological features is preserved;

- Family relationships, religion, a positive relationship with the land, knowledge of specific local conditions and ability to work in them, are decisive;

- Historical diligence of local people, their common sense and ability to use rational approaches in developing their native region;

- Favourable population age structure with a dominance of working-age population and migration of middle-aged and younger generations from work or study outside the region, creates an opportunity to employ these age groups in the agricultural sector; and

- Preservation of folk traditions and high cultural and historical consciousness of the population, together with favourable environmental conditions and no significant negative impacts on environmental components, are a prerequisite for the development of economic activities in the region, particularly activities related to rural tourism.

\subsection{Threats to traditional agricultural landscapes}

The main threats to TALs were determined by comparing conflicts between the current ecosystem status and the main potential and actual drivers. The future of TALs is threatened mainly by:

- Inappropriate economic conditions for successful TAL agricultural management caused by low profitability management, high input, low income, low market prices for products, poor trade opportunities and an inappropriate competitive environment; 
- Lack of human resources is a consequence of the gradual ageing of farmers and the younger generation's loss of interest in traditional management;

- Intensive pressure of owners and developers for changing agricultural land into built-up areas and other land use, while not preserving traditional architecture;

- Insufficient legislative support for TALs protection fails to provide adequate protection for valuable landscape structures, low support from grant schemes, as well as administrative barriers to obtaining sufficient resources;

- Weak support of national agricultural policies for preservation and development of traditional farming;

- Poor TAL publicity and diminished appreciation of both their value and ecosystem services they provide for society;

- Insufficient research and monitoring of TAL changes with the accompanying lack of awareness about threats to TALs.

These all result in diminishing traditional land use, including subsequent land abandonment, grassland overgrown by shrubs and spreading synanthropic species.

\subsection{Modelling scenarios}

The preservation of TALs depends on human activity and specifically on agricultural management. The future development of agricultural landscapes depends on trends in land use and the institution of conditions which prevent possible threats. Although an ecologically stable and visually beautiful heterogeneous landscape attracts people more than homogeneous areas (Palang et al., 2000), final outcomes appear influenced by economic decisions (Penker, Wytrzens, 2005), human driving forces often producing negative results (Dramstad, Fjellstad, 2011). One positive aspect of landscape planning exists in the visual presentation of landscape and in consequent choices of future landscape evolution. Such visualization is supported by modern research methods, which allow a relatively rapid modelling of basic conditions throughout the country (Jakab, Petluš, 2012). Our research focuses on the major drivers: economic development, land abandonment and agro-environmental policies. Three main scenarios for the agricultural landscape are developed in this study area (Fig. 4 - see cover p. 4):

- A disintegrating trend in TALs, with the gradual extinction of the mosaic, when threats become actuality through economic development pressures; the trend in this scenario is tourism development with built-up areas. This occurs in winter tourism development where the most valuable terraced fields surrounding the village are destroyed due to the construction of ski facilities. Further economic development involves agricultural intensification unrelated to the existing severe natural conditions, as occurred during agricultural collectivization.

- The maintenance of traditional TAL management with optimal land-use when threats are minimized. This scenario provides favourable conditions for biodiversity support in agricultural management and ensures optimal utilization of agri-environmental schemes. Although the current agricultural cooperative utilizes an agrienvironmental scheme, it only supports biodiversity in species-rich grasslands without considering the tessellated landscape pattern and more difficult management conditions.

- This scenario depicts land abandonment linked to rural landscape depopulation, which occurs as the local population's interest in traditional management wanes. Here, the most valuable TAL structures become the most threatened because of their low productivity and difficult management. These include terraces and mosaics of small arable fields and grasslands.

Answers to the questionnaire provided by local stakeholders revealed that respondents perceive two main threats to the extinction of TALs - intensive agricultural land use and land abandonment. However, their levels of concern for these two threats differ (Baránková et al., 2011).

\section{Strategy for the protection and management of TALs}

TAL protection and management strategies were developed from analytic, synthetic and evaluation research results. This comprised two elements: strategic development goals and a proposal for TAL practical management measures.

\subsection{Strategic Development Goals}

It is necessary to provide effective management in order to protect and sustain TAL use because agriculture is not a permanent job for more than $70 \%$ of farmers who also work outside the village (Bezák, Dobrovodská, 2012). Current farmers have a strong link to their land, but this is unsustainable for the long-term TAL protection and maintenance, and we therefore define the following seven strategic objectives:

1. To ensure sustainable development and improved human resources in TAL management and protection by implementing the following measures:

- Increasing public awareness and fostering the population's positive attitude to TAL; 
- Strengthening education and training focused on local specifics and values; to encourage the younger generation to respect the landscape and its historical and landscape values, and to promote the significance and benefits of ecological management;

- Encouraging farmers to develop and continue their family farming traditions, to further develop pride in the specifics of their countryside and to ensure the transfer of TAL management knowledge and experience from generation to generation; and

- Creating a motivational environment for young people to remain in their village and to continue in traditional land management.

2. To support appropriate socio-economic conditions for TAL management, tourism and regional development utilizing the following measures:

- Strengthening grant and subsidy schemes for TAL management and protection and adapting them to small private farmers' needs;

- Creating a favourable environment for economic marketing of produce by increasing market prices, by ensuring a favourable competitive environment and by increasing domestic sales wherever possible;

- Strengthening tourism development in the community by developing appropriate support services, this especially means to foster traditional regional folk festivals and present folk crafts; and

- Increasing local government support by funding schemes for traditional management activities.

3. To strengthen the promotion of the culturalhistorical landscape and natural TAL values by implementing the following measures:

- Enhancing public awareness of TAL values;

- Promoting natural and cultural values of a specific rural region, this can be achieved by editing promotional material, promoting regional professional events, publicizing on websites and cooperating with regional government travel agencies, tourist information centres and tourist facilities in the village and its surrounds;

- Organizing additional local promotional events, excursions and field trips aimed at increasing awareness of folk customs and traditions and arousing people's positive attitude to TALs; and

- Extending the existing nature trails and advertising them on billboards extolling TAL values.

4. To eliminate threats to TALs by implementing the following:

- Ensuring appropriate management of farming sites vulnerable to erosion and landslide processes;

- Eliminating negative disturbances during bird nesting seasons;

- Preventing TAL abandonment;
- Eliminating illegal landfill and creation of wild dumps that threaten not only the landscape, but also the aesthetic quality of TALs;

- Reducing or completely eliminating the application of fertilizers and other chemicals;

- Reducing the pressure of developers to construct buildings, which conflict with traditional architecture;

- Following essential environmental principles in organic farming, including eliminating soil and water pollution from the application of pesticides and reducing damage from over-loaded vehicles;

- Excluding activities likely to contaminate water sources such as intensive grazing and the application of liquid and solid organic fertilizers, namely in areas with significant groundwater resources; and

- Proposing assessment policies to ensure that management practices follow the legislation enacted for the assessment of environmental impacts.

5. To strengthen the protection of TALs by implementing the following measures:

- Applying management policy, which protects TALs in spatial planning documents, and particularly in land-use planning documentation;

- Initiating gradual legislative protection for TALs by declaring them significant landscape features and protected areas, and including them in a network of territorial systems of ecological stability so that appropriate management can support their conservation and protection;

- Proposing a possible inclusion of TALs in grassland and pasture land, and promoting architectural elements ratification in UNESCO cultural heritage sites;

- Reconciling conservation interests in nature and natural resources with those serving individual farmers' needs; and

- Reconciling the protection of TALs with conflicting activities of socio-economic development, particularly in the development of sports and recreational activities such as ski tracks and related services.

6. To provide TAL research and monitoring.

7. To apply appropriate management practices in TAL areas by implementing the following important measures:

- Fostering the respect of typical settlement form and structure, characterized by (1) the ethno-cultural and socio-economic region, (2) natural-climatic zones, (3) the districts' valuable cultural, historical and social phenomena, and (4) potential economic advantages for the entire community by fostering the progressive development of appropriate summer 
and winter tourism activities, especially those focused on cultural, cognitive and agro tourism.

\subsection{Practical management measures for traditional agricultural landscapes}

The proposal for TAL practical management measures focuses on the optimal land use of habitats in different TAL types. This is necessary for their general favourable conservation status and for habitat biodiversity conservation, in particular. The proposal is based on the analysis of TAL landscape structure and typology, and on biotic and abiotic conditions, in conjunction with the biodiversity assessment and evaluation of TAL ecological and cultural-historical values. A model for the practical management of TAL sites in the entire pilot study area was designed from our research results on the monitored plots.

The practical management design covers the following types of TAL structures:

a) extensively utilized areas of (1) pastures with muddy terraces, (2) calcareous grasslands with rocky mounds, (3) silicaceous grasslands with rocky mounds, and (4) grasslands with muddyrocky terraces; and

b) intensively utilized areas of (5) grasslands and (6) large-block arable fields, plus mosaics of (7) grasslands and arable fields with muddy terraces, and (8) grasslands and arable fields with muddy-rocky mounds, together with semi-natural meadows.

Management measures are focused on the optimal use of the area, with emphasis placed on the area's natural and cultural values. The measures considered the needs, limitations and optimal execution time required for management activities such as mowing, grazing, tree removal, and use of organic fertilizers.

\section{Discussion and conclusion}

The strategy for the protection and management of TALs herein is oriented towards

1. Optimal multifunctional utilization and management of TAL traditional and sustainable development in the investigated landscapes;

2. Landscape biodiversity maintenance through the application of an agro-environmental scheme; and

3. Potential of TALs for tourism development.

The ecological management proposal encourages not only valuable habitat protection, but it ensures a positive impact on the health of local inhabitants and visitors by reducing stress phenomena from air, soil and water pollution, together with the provision of healthy organic products.
Liptovská Teplička is the highest situated village with traditional agriculture in Slovakia, where meadows and pastures have been developed since Goral colonization. The rugged topography, steep slopes and shallow rocky soils encouraged the local population to maintain maximum use of their agricultural land in the formation of characteristic TALs. This produced a narrow mosaic strip of arable land plots, grasslands and FAR. The rugged topography prevented excessive land reclamation during the collectivization period (Dobrovodská, 2006), and agricultural intensification was recorded on only $1.56 \%$ of this territory (Špulerová, Dobrovodská, 2010). Land use change evaluation revealed a declining trend in grasslands. This was previously due to land use changes from grassland to cropland, but is currently caused by abandonment and subsequent succession (Bezák, 2009; Kandrík, Oláh, 2010). Here, the main agricultural landscape organization is the Liptovská Teplička Agricultural Cooperative, which introduced organic farming in 1996. The TAL biodiversity assessment proves that the current management is favourable and well accepted. The results indicate that TALs are important stabilizing elements in agricultural land, and their presence and traditional utilization significantly increase biodiversity in these areas. The superiority of TAL biodiversity over intensely cultivated areas was confirmed in all TAL structures and also on FAR, so these may be classified as islands of species-rich habitats providing refuge in the landscape matrix.

The current state of TALs in the Liptovská Teplička pilot area is quite favourable, so for the ongoing TAL preservation we recommend maintaining the current and proposed management measures and principles of the Agricultural Cooperative Liptovská Teplička's organic farming, ably supported by agrienvironmental schemes. TALs are already rare in Slovakia and adequate attention is essential for these less accessible and remote marginal areas with extreme natural conditions. It is imperative that these TALs are classified as significant landscape features and important local bio-centres because of their dual benefits for society and the environment.

Implementation of the Common Agricultural Policy has provided greater financial support to recommence agricultural activities after joining the European Union. Nevertheless, concern remains about biodiversity maintenance in mountain grassland communities, where access is limited and specific extensive management is still required (Bezák, Halada, 2010). On the other hand, in order to establish support for TAL in existing instruments, there has to be contrived inclusion of both agricultural heritage and bio-diversity in existing international regulatory 
objectives for TAL preservation (Harrop, 2007). Therefore, it is essential that new instruments and policy documents directly supporting TAL clearly define this aspect as a prime goal of conservation policy, and ensure TAL definition and inclusion in the national agri-environmental grant scheme.

The natural and cultural-historical landscape value reflects the relative importance of landscape in sustaining biodiversity, and the preservation of this value demands ongoing development strategies formulated for landscape planning on a landscape-applicable scale (Wrbka et al., 2004). A successful example of a funded development strategy was illustrated in the monitoring of an agri-environmental scheme of hay meadows in Switzerland. There, financial subsidies were justified and highly rewarded by increased species richness of vascular plants, grasshoppers and wild bees. The species richness in this hay meadow agri-environment scheme far surpassed species richness on untreated control meadows (Knop et al., 2006).

\section{Acknowledgement:}

This contribution was prepared in the grant project of the Ministry of Education of the Slovak Republic and the Slovak Academy of Sciences No. 2/0051/11: "Significance and ecosystem services of historical structures of agricultural landscapes", and the project of the Slovak Research and Development Agency No. APVV-0669-11: "Atlas of landscape archetypes of Slovakia".

\section{References:}

ANDERSEN, E. et al. (2003): Developing a High Nature Value Farming area indicator. Report to the European Environment Agency, Copenhagen.

ANTROP, M. (2005a): Why landscapes of the past are important for the future? Landscape and Urban Planning, Vol. 70, p. 21-34.

ANTROP, M. (2005b): From holistic landscape synthesis to transdisciplinary landscape management. In: Tress,B., Tress, G., Fry, G., Opdam, P. [eds.]: From Landscape Research to Landscape Planning: Aspects of Integration, Education and Application, Wageningen UR Frontis Series, No. 12, Springer Science + Business Media, p. 27-50. Available at: http:// library.wur.nl/frontis/landscape_research/03_antrop.pdf.

BARÁNKovÁ, Z., DOBROVOdSKÁ, M., ŠTEFUnKOVÁ, D., BABICOVÁ, D., MOYZEOVÁ, M., PETROVIČ, F. (2011): Participation of local people on identifying the landscape values and future development in historical agricultural landscapes. Ekológia (Bratislava), Vol. 30, No. 2, p. 216-228.

BENAYAS, J. M. R., BULLOCK, J. M. (2012): Restoration of Biodiversity and Ecosystem Services on Agricultural Land. Ecosystems, Vol. 15, No. 6, p. 883-899.

BEZÁK, P. (2009): Driving forces and pressures of the landscape and biodiversity change in Slovakia. In: Geography and sustainable development: proceedings. Macedonian Geographical Society, Skopje, p. 9-18.

BEZÁK, P., DOBROVODSKÁ, M. (2012): Stakeholders' perception of traditional agricultural landscape and its management (3 Slovak case studies). In: Forum Carpaticum 2012: from Data to Knowledge, from Knowledge to Action. ILE SAS Nitra, p. 204-205. Available at: http://uke.sav.sk/fc/fc_2012/Download/FC2012_Conference_Abstracts.pdf.

BEZÁK, P., HALADA, L. (2010): Sustainable management recommendations to reduce the loss of agricultural biodiversity in the mountain regions of NE Slovakia. Mountain Research and Development, Vol. 30, No. 3, p. 192-204.

BRANDT, J., PRIMDAHL, J., REENBERG, A. (1999): Rural land-use and dynamic forces - analysis of 'driving forces' in space and time. In: KRÖNERT R., BAUDRY J., BOWLER I. R., REENBERG A. [eds.]: Land-use changes and their environmental impact in rural areas in Europe. UNESCO, Paris, France, p. 81-102.

CULLOTTA, S., BARBERA, G. (2011): Mapping traditional cultural landscapes in the Mediterranean area using a combined multidisciplinary approach: Method and application to Mount Etna (Sicily; Italy). Landscape and Urban Planning, Vol. 100, p. 98-108.

DANKANINOVÁ, L., GAJDOŠ, P. (2011): Hodnotenie biodiverzity pavúčích spoločenstiev v historických štruktúrach pol'nohospodárskej krajiny Liptovská Teplička. In: KRUMPÁLOVÁ, Z. [ed.]: 9. arachnologická konferencia: Východná, 14.-18.9.2011. KEE UKF v Nitre, p. 16-17.

DOBROVODSKÁ, M. (2006): The development of relations between man and landscape in a historical mountain agricultural landscape of Slovakia. Ekológia (Bratislava), Vol. 25, suppl. 1, p. 38-48.

DRAMSTAD, W. E., FJELLSTAD, W. J. (2011): Landscapes: Bridging the gaps between science, policy and people. Landscape and Urban Planning, Vol. 100, p. 330-332.

ELLIS, E. C. et al. (2009): Estimating long-term changes in China's village landscapes. Ecosystems, Vol. 12, No. 2, p. $279-297$. 
EEA/UNEP (2004): High nature value farmland. European Environmental Agency and UNEP regional office for Europe. Office for official publications of the European Communities, Luxembourg. Available at: http://www.eea.europa.eu/publications/ report_2004_1 European landscape convention, Florence, 20.X.2000, Council of Europe Treaty Series No. 176 (2004).

EU/1257/99: COUNCIL REGULATION (EC) No. 1257/1999 of 17 May 1999 on support for rural development from the European Agricultural Guidance and Guarantee Fund (EAGGF) and amending and repealing certain Regulations.

FAZEKAŠOVÁ, D., BOLTIŽIAR, M., BOBUL'SKÁ, L., KOTOROVÁ, D., HECL, J., KRNÁČOVÁ, Z. (2013, in press): Development of soil parameters And changing landscape structure in conditions of cold mountain climate (Case Study LiptovskÁ Teplička) In: Ekológia (Bratislava), roč. 32, Vol. 2.

HALADA, L', HALABUK, A., GAJDOŠ, P. (2011): Pol’nohospodárska krajina s vysokými prírodnými hodnotami. Životné prostredie: revue pre teóriu a starostlivost̉ o životné prostredie, Vol. 45, No. 1, p. 12-16.

HARROP, S. R. (2007): Traditional agricultural landscapes as protected areas in international law and policy. Agriculture, Ecosystems \& Environment. Vol. 121, No. 3, p. 296-307.

JAKAB, I., PETLUŠ, P. (2012): Development of a Program Tool for the determination of the Landscape Visual Exposure Potential. In: Models of the Ecological Hierarchy: From Molecules to the Ecosphere. Elsevier B.V. Amsterdam, p. 375-390.

KANDRÍK, R., OLAH, B. (2010): Land use development in the central part of the Spiš region (Slovakia) since the $18^{\text {th }}$ century. Moravian Geographical Reports, Vol. 18, No. 4, p. 10-20.

KIZOS, T., DALAKA, A., PETANIDOU, T. (2010): Farmers' attitudes and landscape change: evidence from the abandonment of terraced cultivations on Lesvos, Greece. Agric Hum Values, No. 27, p. 199-212.

KNOP, E., KLEIJN, D., HERZOG, F., SCHMID, B. (2006): Effectiveness of the Swiss agri-environment scheme in promoting biodiversity. JOURNAL OF APPLIED ECOLOGY. Vol. 43, No. 1, p. 120-127.

LIESKOVSKÝ, J., KANKA, R., BEZÁK, P., ŠTEFUNKOVÁ, D., PETROVIČ, F., DOBROVODSKÁ, M. (2013), "Driving forces behind vineyard abandonment in Slovakia following the move to a market-oriented economy." Land Use and Policy, No. 32, p. 356-365.

MARINI, L., KLIMEK, S., BATTISTI, A. (2011): Mitigating the impacts of the decline of traditional farming on mountain landscapes and biodiversity: a case study in the European Alps. Environmental science \& policy, Vol. 14, No. 3, p. $258-267$.

MOYZEOVÁ, M. (2012): Pozitívne socioekonomické javy a kvalita životného prostredia (na príklade obce Liptovská Teplička). Ekologické štúdie, Vol. 3, No. 1, p. 20-27.

PALANG, H., ALUMÄE, H., MANDER, Ü. (2000): Holistic aspects in landscape development: a scenario approach. Landscape and Urban Planning, Vol. 50, p. 85-94.

PARACCHINI, M. L., TERRES, J. M., PETERSEN, J. E., HOOGEVEEN, Y. (2006): Background document on the methodology for mapping High Nature Value Farmland in EU 27. EC JRC, EEA, 32 pp.

PEDROLI, B., VAN DOORN, A., DE BLUST, G., PARACCHINI, M. L., WASCHER, D. BUNCE, F. [eds.] (2007): Europe's living landscapes. Essays on exploring our identity in the countryside. LANDSCAPE EUROPE / KNNV.

PENKER, M., WYTRZENS, H. K. (2005): Scenarios for the Austrian food chain in 2020 and its landscape impacts. Landscape and Urban Planning, Vol. 71, p. 175-189.

PETANIDOU, T., KIZOS, T., SOULAKELLIS, N. (2008): Socioeconomic Dimensions of Changes in the Agricultural Landscape of the Mediterranean Basin: A Case Study of the Abandonment of Cultivation Terraces on Nisyros Island, Greece. Environmental Management, Vol. 41, p. 250-266.

PETIT, C., KONOLD, W., HÖCHTL, F. (2012): Historic terraced vineyards: Impressive witnesses of vernacular architecture. Landscape History Vol. 33, No. 1, p. 5-28.

PLASSMANN, M. (2013): The high nature values farming concept throughout EU 27 and its maturity for financial support under the CAP. HNV and CAP task 1 Report for Slovakia. DAPHNE - Institute of Applied Ecology Slovakia.

PLIENINGER, T., HÖCHTL, F., SPEK, T. (2006): Traditional land-use and nature conservation in European rural landscapes. Environmental science \& policy, No. 9, p. 317-321.

RUŽICKA, M., MIKLOS, L. (1990): Basic premises and methods in landscape ecology planning and optimization. In: Zonneveld, I. S., Forman, R. T. T. [eds.]: Changing landscape, an ecological perspective. Springer-Verlag, p. 233-260.

RUŽIČKOVÁ, H., DOBROVODSKÁ, M. (2006): Druhovo bohaté trávne porasty v chotári obce Liptovská Teplička produkt intenzívneho a polointenzívneho hospodárenia. In: NOVÁK, J., MACEJKOVÁ, L., STANKOVIČOVÁ. L'. [eds.]: Podtatranské pažite: zborník referátov zo sympózia. SPU Nitra, p. 44-49.

SUPUKA, J., STEPANKOVA, R. (2004): Characteristic and marks of cultural landscape of Slovakia. Ekológia (Bratislava). Vol. 23, Suppl. 1, p. 333-339. 
ŠPULEROVÁ, J., DOBROVODSKÁ, M. (2010): Significance of landscape diversity of historical agricultural landscape structures on the example of Liptovská Teplička study area. In: NOVÁČEK, P., HUBA, M. [eds.]: Udržitelný rozvoj - stav a perspektivy v roce 2010: Sborník z konference. Olomouc, UP Olomouc, p. 241-251.

ŠPUlerovÁ, J., DOBROVODSKÁ, M., LIESKOVSKÝ, J., BAČA, A., HALABUK, A., KOHÚT, F., MOJSES, M., KENDERESSY, P., PISCOVÁ, V., BARANČOK, P., GERHÁRTOVÁ, K., KRAJČI, J., BOLTIŽIAR, M. (2011): Inventory and classification of historical structures of the agricultural landscape in Slovakia. Ekológia (Bratislava), Vol. 30, No. 2, p. $157-170$.

ŠTEFUnKOVÁ D., ŠPUlEROVÁ, J., DOBROVODSKÁ M., MOJSES M., PETROVIČ F. (2013): Traditional agricultural landscapes - a model of detailed land use mapping, Tájökológiai Lapok, Vol. 11, No. 1, p. 1-21.

ŠTEFUNKOVÁ, D., DOBROVODSKÁ, M. (1998): Kultúrno-historické zdroje Slovenska a ich význam pre trvalo udržatelný rozvoj. In: IZAKOVIČOVÁ, Z., KOZOVÁ, M., PAUTDITŠOVÁ, E. [eds.]: Implementácia trvalo udržatelného rozvoja. Bratislava, ÚKE SAV, p. 104-111.

TRESS B., TRESS G. (2001): Capitalising on multiplicity: a transdisciplinary systems approach to landscape research, Landscape and Urban Planning, Vol. 57, No. 3-4, p. 143-157.

VAN EETVELDE, V., ANTROP, M. (2004): Analyzing structural and functional changes of traditional landscapes - two examples from Southern France. Landscape and Urban Planning Vol. 67, No. 1-4, p. 79-95.

VOS, W., MEEKES, H. (1999): Trends in European cultural landscape development: perspectives for a sustainable future. Landscape and Urban Planning, Vol. 46, p. 3-14.

WLO (1998): A new identity for landscape ecology in Europe. A research strategy for the next decade: outlines formulated at the European congress Landscape ecology: things to do, 6-10 October 1997, Amsterdam.

WRBKA, T., PETERSEIL, J., SCHMITZBERGER, I., STOCKER-KISS, A. (2004): Alpine farming in Austria, for nature, culture or economic need? New Dimensions of the European Landscape Book Series: Wageningen ur frontis series, Vol. 4, p. $165-177$.

http://portal.statistics.sk

\section{Authors' addresses:}

Ing. Jana ŠPULEROVÁ Ph.D., e-mail: jana.spulerova@savba.sk RNDr. Marta DOBROVODSKÁ Ph.D., e-mail: Marta.Dobrovodska@savba.sk

RNDr. Zita IZAKOVIČOVÁ Ph.D., e-mail: Zita.Izakovicova@savba.sk

Mgr. Pavol KENDERESSY Ph.D., e-mail: Pavol.Kenderessy@savba.sk

Ing. Dagmar ŠTEFUNKOVÁ Ph.D., e-mail: Dagmar.Stefunkova@savba.sk

Institute of Landscape Ecology SAS

Štefánikova 3, 81499 Bratislava, Slovakia

Doc. RNDr. František PETROVIČ Ph.D.

Department of Ecology and Environmentalist

Faculty of Natural Sciences, Constantine The Philosopher University Nitra

Tr. A. Hlinku 1, 94901 Nitra, Slovakia

e-mail:fpetrovic@ukf.sk

Initial submission 25 April 2013, final acceptance 7 October 2013

Please cite this article as:

ŠPULEROVÁ, J., DOBROVODSKÁ, M., IZAKOVIČOVÁ, Z., KENDERESSY, P., PETROVIČ, F., ŠTEFUNKOVÁ, D. (2013): Developing strategy for the protection of traditional agricultural landscapes based on a complex landscape-ecological evaluation (the case study of mountain landscape in Slovakia). Moravian Geographical Reports, Vol. 21, No. 4, p. 15-26, DOI: 10.2478/mgr-2013-0017. 